\title{
Assessing Progress in Rebuilding the Housing Market in Mississippi in the Wake of Katrina
}

RAND RESEARCH AREAS

THE ARTS

CHILD POLICY

CIVIL JUSTICE

EDUCATION

ENERGY AND ENVIRONMENT

HEALTH AND HEALTH CARE

INTERNATIONAL AFFAIRS

NATIONAL SECURITY

POPULATION AND AGING

PUBLIC SAFETY

SCIENCE AND TECHNOLOGY

SUBSTANCE ABUSE

TERRORISM AND

HOMELAND SECURITY

TRANSPORTATION AND

INFRASTRUCTURE

WORKFORCE AND WORKPLACE

This product is part of the RAND Corporation research brief series. RAND research briefs present policy-oriented summaries of published, peer-reviewed documents.

\section{Corporate Headquarters} 1776 Main Street P.O. Box 2138

Santa Monica, California 90407-2138

TEL 310.393.0411

FAX 310.393 .4818

(c) RAND 2007

www.rand.org n August 2005, Hurricane Katrina devastated the Louisiana and Mississippi coasts, inflicting major damage to commercial property, infrastructure, and housing throughout the region. However, the hurricane's effects were most pronounced in a half-dozen counties, including Mississippi's three coastal counties: Hancock, Harrison, and Jackson. As part of the state's recovery effort, Mississippi’s Governor Haley Barbour appointed the Commission on Recovery, Rebuilding, and Renewal to determine the extent of the damage and to recommend policies to aid in the recovery.

Because of the limited data available immediately after the storm, the full extent of the damage and the specific effects on the Mississippi housing market remained unclear during the commission's work. As a follow-up to the commission's work, RAND researchers developed a comprehensive, quantitative assessment of both the extent and nature of the damage that the hurricane did to the housing stock and the progress toward recovery made since the storm.

\section{How Much Did Katrina Damage the Housing Stock?}

Katrina damaged about 60 percent of the three counties' housing stock, but the extent and intensity of that damage varied substantially depending on the source of that damage. Storm surge alone was responsible for a little more than one-third of the damaged units, and almost half of those units suffered severe damage. Although 45 percent of all the damage to units was caused by wind or rain, the vast majority of that damage was of a limited nature ( $\$ 5,000$ or less). Flooding rarely occurred by itself, but the combination of storm surge and flooding (experienced by about 20 percent of the damaged units) was by far the most devastating - more than 70 percent of those units were severely damaged or destroyed.

\section{Abstract}

Hurricane Katrina created massive damage to Mississippi's Gulf Coast housing stock. This study shows that the storm's damage compounded a preexisting affordable-housing shortage and that, although recovery is proceeding, it has been uneven and will take at least another three years, with a total estimated cost of more than \$4 billion. Access to financing appears to be the single most important obstacle. Immediate pressures to restore the housing stock have taken precedence, but such pressures can conflict with the need to recognize the importance of longerterm mitigation actions.

Despite the widespread nature of the damage, there were significant differences in the extent and intensity of that damage in various submarkets. The most severely affected submarket was multifamily rentals_almost 80 percent of such units were damaged, and one-third of all multifamily units suffered severe or moderate damage (repairs averaging more than $\$ 50,000$ ). About one-half of the single-family residences (owned and rented) suffered damage, and almost 20 percent of all single-family units were severely or moderately damaged. Although between 30 and 50 percent of the owner- and renter-occupied mobile homes, respectively, were damaged, that damage was less severe than in other submarkets.

The damage compounded a preexisting affordable-housing shortage, especially in the rental market in the three counties (as shown in the figure). Prior to Katrina, there were around 25,000 affordable rental-housing units; about 6,000 rental units sustained severe or moderate damage, leaving only a little more than 19,000 units, or a decline of nearly a quarter. While the 
Affordable Rental Housing in Three Counties Before and After Hurricane Katrina

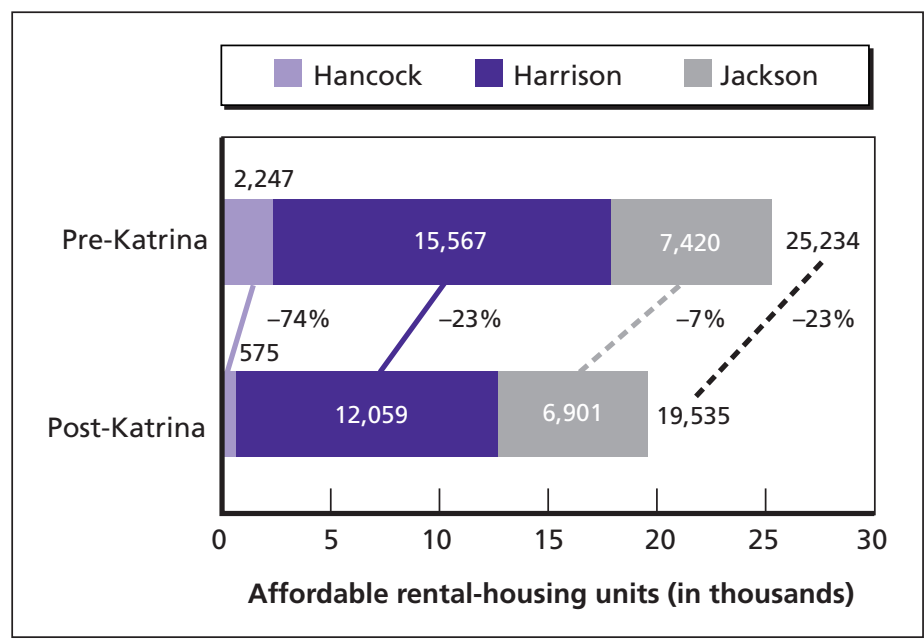

effect on the total affordable stock was most influenced by the damage done to Harrison County (which had 60 percent of the housing stock before Katrina and declined more than a fifth afterward), Hancock County suffered proportionally the most, losing nearly three-quarters of its stock.

\section{What Is the Progress of the Recovery Effort?}

In assessing the recovery effort, the researchers compared information on building permits issued in the months immediately after the storm through the second quarter of 2007. Overall, perhaps as many as 46,000 permits were issued through June 2007, compared with the approximately 77,000 units that were damaged. However, this overall rate of 60 percent varies substantially between incorporated and unincorporated areas.

Our estimates indicate four things about the pace of the recovery. First, the recovery effort got off to a slow start, with relatively few permits being issued in the fourth quarter of 2005 - the first full quarter after the storm. Second, the pace of recovery seems to have moved more rapidly in some submarkets than in others-higher for single-family than multifamily units and higher for moderately than severely damaged units. Third, the costs of repair appear higher than the market values reported in the 2000 census. Fourth, at the current pace, it appears that recovery will take at least another three years, with a total estimated cost of more than $\$ 4$ billion.

\section{What Issues Affect the Recovery Effort?}

In the short-term recovery effort, three issues are critical. First, although the construction sector has geared up its capacity to deal with increased demand, there are signs that the sector's capacity may have peaked by the third quarter of 2006. Additional steps may need to be taken to deal with continued demand.

Second, although multiple sources are available to finance recovery, a rapid increase in housing values and high rebuilding costs appear to have left gaps in the financing picture. This situation appears to be most acute for those who were un- and underinsured, those whose properties were most severely damaged, and those who were landlordsespecially those with large, multiunit rental properties.

Finally, the very tight market for affordable housing pre-Katrina, the loss of a significant portion of the rental stock, a 20 percent increase in rents, and a substantial drop in employment have created a very tight market for those households displaced by the storm. This problem is particularly acute in the affordable-rental sector. Alleviating this problem is important in the recovery of the housing market and in economic recovery more generally.

Beyond these three shorter-term issues, it is important to recognize the potential tensions between the short-term goal of a speedy recovery and the longer-term need to take mitigation measures to protect the region from future storms. Although state and local officials are aware of the need, the experience after Hurricane Camille suggests that carrying through on these intentions often requires considerable resolve. Indeed, as the recovery period since the storm lengthens, political pressures may well increase to expedite the short-term recovery, even at the cost of longer-term mitigation efforts. Such pressures may be difficult to resist, given the political context of local planning decisions.

This research brief describes work done for the RAND Gulf States Policy Institute, a partnership between RAND and seven universities in the U.S. Gulf Coast region, that is housed within RAND Infrastructure, Safety, and Environment. The work is documented in Post-Katrina Recovery of the Housing Market Along the Mississippi Gulf Coast, by Kevin F. McCarthy and Mark Hanson, TR-511-OA/MAR/NAR (available at http://www.rand.org/pubs/technical_reports/TR511/), 2007, 150 pp., \$25, ISBN: 978-0-8330-4293-4. The RAND Corporation is a nonprofit research organization providing objective analysis and effective solutions that address the challenges facing the public and private sectors around the world. RAND's publications do not necessarily reflect the opinions of its research clients and sponsors. RAND $^{\circledR}$ is a registered trademark. 


\section{RAND GULF STATES POLICY INSTITUTE}

THE ARTS

CHILD POLICY

CIVIL JUSTICE

EDUCATION

ENERGY AND ENVIRONMENT

HEALTH AND HEALTH CARE

INTERNATIONAL AFFAIRS

NATIONAL SECURITY

POPULATION AND AGING

PUBLIC SAFETY

SCIENCE AND TECHNOLOGY

SUBSTANCE ABUSE

TERRORISM AND HOMELAND SECURITY

TRANSPORTATION AND INFRASTRUCTURE

WORKFORCE AND WORKPLACE
This PDF document was made available from www.rand.org as a public service of the RAND Corporation.

This product is part of the RAND Corporation research brief series. RAND research briefs present policy-oriented summaries of individual published, peerreviewed documents or of a body of published work.

The RAND Corporation is a nonprofit research organization providing objective analysis and effective solutions that address the challenges facing the public and private sectors around the world.

\section{Support RAND}

$\underline{\text { Browse Books \& Publications }}$

Make a charitable contribution

For More Information

Visit RAND at www.rand.org

Explore RAND Gulf States Policy Institute

View document details

Limited Electronic Distribution Rights

This document and trademark(s) contained herein are protected by law as indicated in a notice appearing later in this work. This electronic representation of RAND intellectual property is provided for non-commercial use only. Unauthorized posting of RAND PDFs to a non-RAND Web site is prohibited. RAND PDFs are protected under copyright law. Permission is required from RAND to reproduce, or reuse in another form, any of our research documents for commercial use. For information on reprint and linking permissions, please see $\underline{\text { RAND Permissions. }}$ 